B210 3 波長同時計測を目的とした高速ビデオカメラの 画素単位の位置・感度調整機構

江藤剛治*, 测 幸男*，山川昌文 $O^{* *}$ ，竹原幸生*

*近幾大学 理工学部, **熊野工業高等専門学校

A Mechanism for Pixel-based Adjustment of Displacement and. Sensitivity for Three-Wave-Length High Speed Video Imaging

Takeharu ETOH*, Sachio OKI*, Masafumi YAMAKAWA** and Kohsei TAKEHARA*

\begin{abstract}
A technique is presented, which consists of a computer program and ancillary instruments 1 ) to adjust displacement of images taken by two or three image sensors and 2) to calibrate relationship between incident light intensity and corresponding digital output signal, simultaneously. The pixel-based displacement adjustment is made by corresponding a pixel of one image sensor with four pixels adjacent to that point on another sensor. The weighted average of outputs for the four pixels are then multiplied by a coefficient calculated from a pixel-based sensitivity calibration.
\end{abstract}

\title{
1.はじめに
}

これまでの高速撮影技術の多くは, 滈速運動の解析に用いられてきた。一方, 燃娅工 学や材料のプラズマプロセッシングなどの分野では, 物体の運動だけではなく，その温 度場を測定する必要がある. 著者らの一部は, プラズマ溶射プロセス解明のための一連 の検討を行っており，すでに4, 500 pps（Picture per Second）の撮影速度を持つ高速ビデ オカメラ1)を用いて, 音速で飛行する溶射粒子の飛行速度のその場計测に成功し, 同時 に，複数台のカメラで2色温度計を構成することによる速度と温度の同時計測の可能性に． ついて示唆してきた2).

今回開発された3板式高速カラー/マルチフレーミングカメラ3）では奌速カラ一撮影 ともに，光3分割キュービックプリズムあるいはフィルターを交換することによって温度 場と速度場の同時計测が可能になる.この場合，3枚の撮像秦子で得られた画像の・位置 合わせと輝度合わせ」が必要になるが，画像信号は画素単位のディジタル信号として取 り出すことができるため，ソフト的に調整することが可能である．ここでは，画素単位 で「位置合わせ，および輝度合わせ」を行う方法を提案する.

* Kinki University, 3-4-1 Kowakae, Higashi-Osaka, Osaka

**. Kumano Technical College, Arima-Cyo, Kumano, Mie 


\section{2. 位置・感度調整方法}

3 枚の撮像素子から個々に得られた画像の位置合わせ，および灀度合わせの概要はFig. 1 に示したとおりである4-6)．まず，3枚の画像データのうちの 1 枚を基準に，残りの 2 枚の画像データがそれぞれどのように対応しているかを見いだす必夏がある。つまり， 基準となる画像データの各点と残りの画像データそれぞれに対応する各点を関係づける 変換関数を算出する.ささらに，これをFig. 1 に示すように画素単位で行う。

基準となる画像データ内の 1 つの画素の重心（中心）が残りの 2 枚目，あるいは 3 枚 目の画像データのどの位置に対応するかを画像の左上端を原点とする x y 座標で裴し, その中心座摽から近接する最大 4 つの画素を 2 枚目，3 枚目の画像データに対してそれ ぞれ求める.

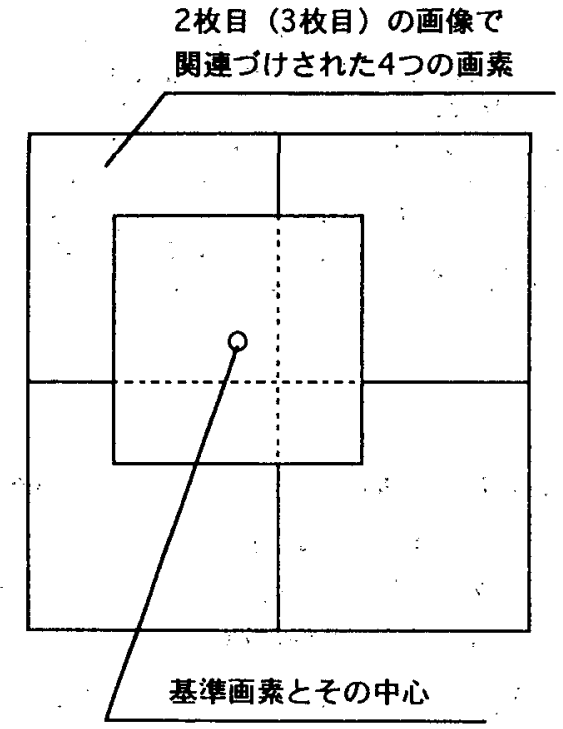

Fig. 1 Relationship between based pixel and four adjacent pixels in second (or third) image data.

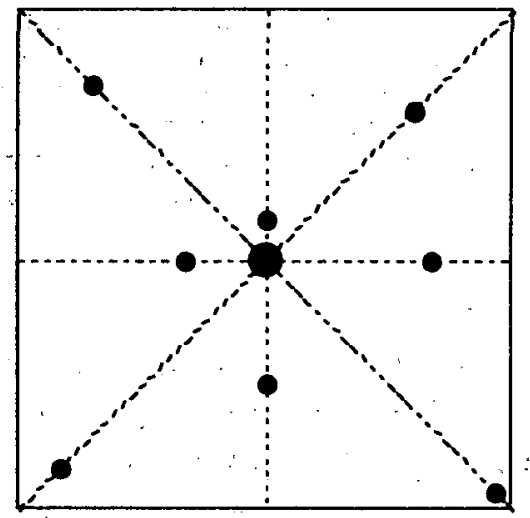

Fig. 2 Chart for displacement adjastment.

また，画像の輝度合わせは，位置合わせで求めた関連した 4 つの画秦のそれぞれの面 積に応じた重み係数を求め，これを基準画像データ内の全画素に対して対応ゔけされた 2 枚目（3 枚目）の画素の重み係数をすべて求めることにより行う。

位置合わせおよび輝度合わせ用チャートとしてFig. 2 に示したパターンを用いる. 3 林 のイメージセンサで得られたこのチャートの円の座標がそれぞれ一致するように变換関 数を求める. また, Fig. 3 に画素単位の画像の位置合わせと輝度合わせのプログラ.ムの流 れを示す. Fig. 2 のチャート撮影後コンピュータに函像データを取り込み，キャリブレー 
ション・フローに入る.まず，3枚のイメージセンサから誈み取った画像データを 2 䛧 化し，それぞれ゙の円を認識し基準画像の円が 2 枚目，3枚目のどの円に対応しているか， それぞれの円゙の重心を求め同定する.

ここで，中心円は他の円より大きく描 いてあり,この大きさの差から中心円を 認識する.ささらに, 各円は中心からの距 離がそれぞれ異なっている.この距離の 違いによって各円を同定する.そして， 同定終了後のそれぞれの重心坐標から２。 次変換の関数を決定する.

ここで，求められた 2 次変換関数をも とに，基準画像の全画素が 2 枚目，ある いは3枚目の画素にどのように関わって いるか，関わり画素の番号とそれ゙ぞれの 画素の重み係数を求める。たとえば,

Fig: 4 において，基準画素番号0の画素が， 2枚目（あるいは3枚目）の画像の画素番 号 (0，1，256，257) の画素に関わって 抢り，基準画素の中心座標が（0.95，

0.95）であったとする. この時，2枚目の 画像の対応する画素の倍号強度は図に示 した4枚の関わり画素のそれぞれa，b，c， dで示した面積率 (重み係数) に対応し た重み付平均で表すことができる.さら に，3枚の撮像秦子の感度の違い，およ び各撮像素子の画素ごとの感度のばらつ きを計測し，前述の重み係数に基づいて 変換係数を求め, 変換テーブルを作成す る. この変換テーブルをカメラに内蔵さ せることによって，効率良く画像の再楎 築が行われる.

このように，カメラ内蔵の，「位置合わ せ・虂度わせ」用変換テーブルを使っ て，3枚のイメージセンサからの得られ たデータを再構筑することにより高速力

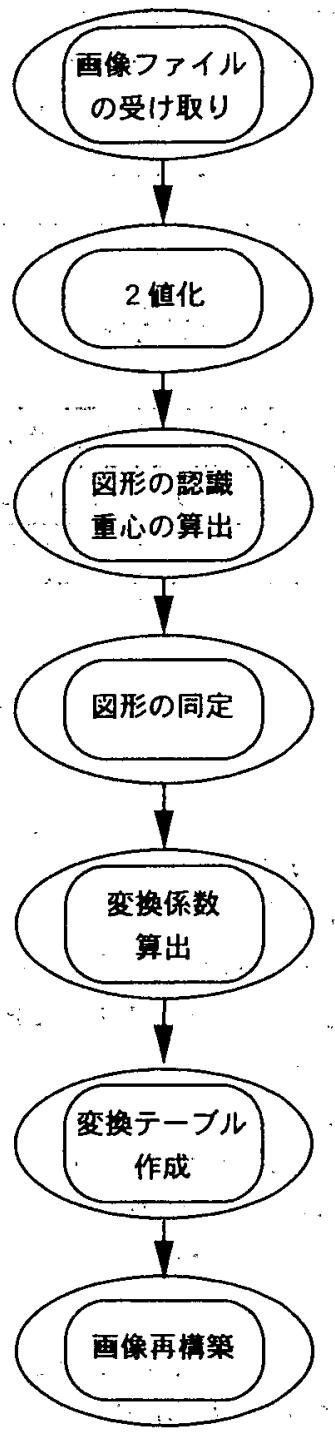

Fig. 3 Calibration process ラー撮影ならびに温度場・速度場の同時 計測が可能となる. 
2枚目（あるいは3枚目）の画像

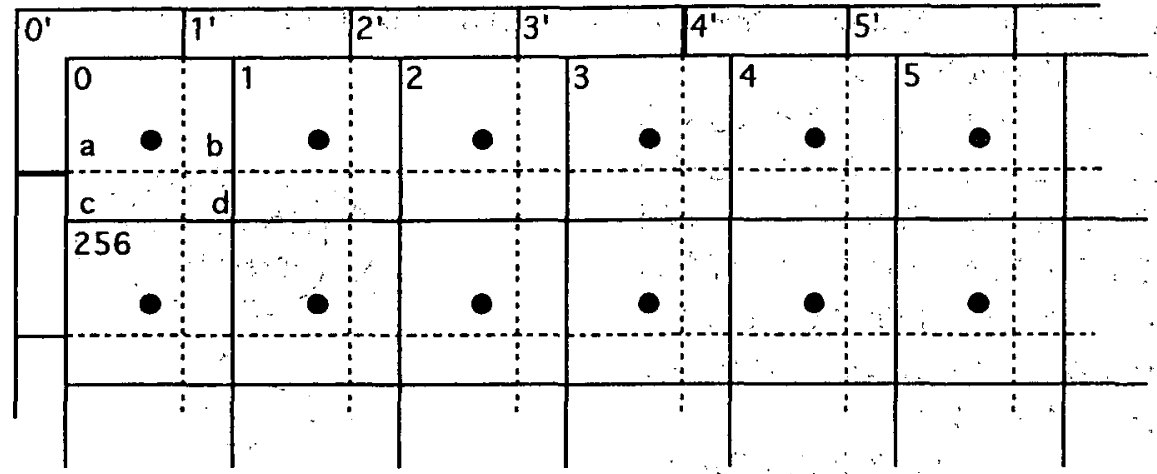

基準画像

\begin{tabular}{|c|c|c|c|c|c|c|c|c|c|c|c|c|}
\hline 基準画素番号 & \multicolumn{4}{|c|}{ 関連面素番号 } & \multicolumn{4}{c|}{ 重み係数 } & \multicolumn{4}{|c|}{ 変換係数 } \\
\hline 0 & 0 & 1 & 256 & 257 & 0.302 & 0.248 & 0.248 & 0.202 & $\alpha$ & $\beta$ & $\chi$ & $\delta$ \\
\hline 1 & 1 & 2 & 257 & 258 & 0.302 & 0.248 & 0.248 & 0.202 & $\varepsilon$ & $\phi$ & $\gamma$ & $\eta$ \\
\hline$:$ & $:$ & $:$ & $:$ & $:$ & $:$ & $:$ & $:$ & $:$ & $:$ & $:$ & $:$ & $:$ \\
\hline
\end{tabular}

Fig. 4 Transformation table.

3.おわりに

立方体型光分割プリズムを使って入射光をRGBに3 分割し， 3 枚のイメージセンサ で得られたR GBそれぞれの画像信号を，ソフト的に画素単位で「位置合わせ・熭度合 わせ」を行い，高速カラー撮影ならびに温度計測を可能にした。

\section{参考文献}

1）江藤剛治；4, 500 枚・秒の高速ビデオカメラ, テレビジョン学会誌; Vol. 46, No. 5, pp. 543 - 545, 1992.

2) S. Oki et al. ; Measurement of Spraying Particle Behavior by High Speed Video Camera System, Proc.ITSC, pp. $441-444,1995$.

3）江藤剛治, 竹原幸生, 过 政孝, 久米英浩 ; 3板式高速カラービデオ・マルチフレー ミングカメラ，本論文集，B-209，1996.

4) Brown，L.G.(白井良明 訳) ; 画像の位置合わせ手法の概観，b i t 别冊；コンピュー タ・サイエンス, pp.77-119, 1994.

5）本多庸悟 他; 画像処理と視賞認識，第 1 版，才ーム社，1995.

6) 近藤次郎; 数学モデルー現象の数式化一, 第 6 刷, 丸善(株), 1987. 